\title{
ANALISIS PUTUSAN PENGADILAN NEGERI SAMPANG NOMOR 69/Pid.B/2012/PN.Spg. PRESPEKTIF HAK KEBEBASAN BERAGAMA DI INDONESIA
}

\author{
Muwaffiq Jufri \\ Program Studi Magister Ilmu Hukum Fakultas Hukum Universitas Brawijaya \\ Jl. M.T. Haryono 169 Malang 65145 \\ email: muwaffiq.jufri@gmail.com
}

\begin{abstract}
: the rights and freedom of religion is a constitutional right of citizens as guaranteed by the constitution. However, conflict, violence and prohibition on the right is still prevalent in various regions in Indonesia, only one is against followers of Syi' ah in Sampang. These events drove Tajul Muluk be convicted by Sampang District Court's Decision No.69/Pid.B/2012/PN.Spg. This event seemed to signal that the state is unable to protect the constitutional rights of citizens to believe in and follow a religion. Even countries participated as an actor against the rise of violence and a rejection of the Syi' ah community in Sampang. The attitude of such state is a form of a waiver of the principle of religious freedom guaranteed by the constitution.
\end{abstract}

Keywords: rights, freedom of religion, decisions, and tajul muluk

\begin{abstract}
Abstrak: hak dan kebebasan beragama merupakan hak konstitusional warga negara karena telah dijamin oleh konstitusi. Namun demikian, konflik, kekerasan dan pelarangan terhadap hak ini masih banyak ditemui di berbagai wilayah di Indonesia, salah-satunya ialah terhadap penganut paham Syi' ah di Sampang. Peristiwa tersebut mengantarkan Tajul Muluk menjadi terpidana melalui Putusan Pengadilan Negeri Sampang Nomor: 69/Pid.B/2012/PN.Spg. Peristiwa ini seolah memberikan tanda bahwa negara tidak mampu melindungi hak konstitusional warga negara dalam meyakini dan menganut suatu agama. Bahkan negara seolah ikut menjadi aktor terhadap munculnya aksi-aksi kekerasan dan penolakan kepada komunitas Syi'ah Sampang. Sikap negara yang demikian merupakan bentuk pengenyampingan terhadap prinsip kebebasan beragama yang telah dijamin oleh konstitusi.
\end{abstract}

Kata kunci: hak, kebebasan beragama, putusan, dan tajul muluk

Berdasarkan ketentuan Pasal 1 ayat (2) UndangUndang Dasar Negara Republik Indonesia Tahun 1945 menegaskan bahwa Negara ini didasarkan pada hukum. Ketentuan tersebut berimplikasi pada segala tindakan yang dilakukan dalam rangka menjalankan roda organisasi negara harus didasarkan pada hukum yang berlaku. Terkait dengan negara hukum, R. Soepomo seperti yang dikutip oleh A. Mukhtie Fadjar, mengemukakan pandangannya bahwa Negara hukum ialah Negara yang tunduk pada hukum, peraturan-peraturan hukum berlaku bagi segala badan dan alat-alat perlengkapan Negara. Negara hukum juga akan menjamin tertib hukum dalam masyarakat yang artinya memberikan perlindungan hukum, serta terjadi hubungan timbale-balik antara hukum dan kekuasaan (Fadjar, 2004:7).
Dalam perkembangannya, aspek negara hukum tidak hanya terfokus pada masalah peraturan dan tertib hukum, tetapi juga pada upaya perlindungan terhadap prinsip-prinsip hak asasi manusia (HAM) (Muhshi, 2014:18). Hak Asasi Manusia menurut pasal 1 Ayat (1) UU No. 39 Tahun 1999 adalah seperangkat hak yang melekat pada hakikat dan keberadaan manusia sebagai makhluk Tuhan Yang Maha Esa dan merupakan anugerah-Nya yang wajib dihormati, dijunjung tinggi dan dilindungi oleh negara, hukum, Pemerintah, dan setiap orang demi kehormatan serta perlindungan harkat dan martabat manusia. Negara hukum modern menghendaki perlindungan dan penegakan terhadap HAM. Seperti yang disampaikan oleh Van Wijk yang dikutip oleh A. Hamid S. Attamimi bahwa Negara hukum 
(rechtsstaat) memiliki unsur-unsur sebagai berikut: (a) pemerintahan menurut hukum (vetmatig besture), dengan bagian-bagiannya tentang kewenangan yang dinyatakan dengan tegas, tentang perlakuan yang sama, dan kepastian hukum; (b) jaminan atas hak-hak asasi; (c) pembagian kekuasaan dengan bagian-bagiannya tentang struktur kewenangan atau desentralisasi dan tentang pengawasan dan kontrol. Dengan demikian, jaminan atas hak asasi manusia menjadi hal yang wajib pemenuhannya dalam suatu negara yang berlandaskan hukum.

Sebagai negara hukum, Indonesia telah memberikan aturan mengenai perlindungan terhadap prinsip-prinsip HAM, ini bisa dibuktikan dengan adanya ketentuan pasal 28a-28j UUD NRI ' 45 yang khusus membahas tentang HAM. Tentu keberadaan pasal-pasal tersebut menjadi angin segar dalam upaya melindungi kepentingan rakyat dari tindakan-tindakan yang berpotensi merenggut hak asasi yang seharusnya mereka miliki.

Menariknya, ketentuan kebebasan beragama mendapatkan posisi terhormat dalam UUD NRI '45. Kebebasan beragama secara jelas dinyatakan dalam ketentuan pasal 28E yang berbunyi "bahwa setiap orang bebas memeluk agama dan beribadah menurut agamanya". Menurut Agung Ali Fahmi, Kata "setiap orang" berarti "semua orang", tidak membedakan ras, suku, warga Negara mana, dan latar belakang primordial lainnya. Dengan demikian, pasal ini memang ditujukan untuk melindungi hak asasi manusia yang paling asasi, berlaku universal dan lintas batas territorial, adat, budaya, dan perbedaan soaial-politik lainnya.

Selain itu, Pasal 28 E ayat (2) UUD NRI ' 45 juga menegaskan bahwa Setiap orang berhak atas kebebasan meyakini kepercayaan, menyatakan pikiran dan sikap, sesuai dengan hati nuraninya. Pasal ini seolah memperjelas bahwa kebebasan beragama tidak bisa dipisahkan dari kebebasan untuk meyakini kepercayaan, menyatakan pikiran dan sikap sesuai dengan hati nuraninya, kesemua unsur itu merupakan satukesatuan yang tidak bisa terpisah antara satu dengan yang lainnya.

Namun demikian, jaminan konstitusi terhadap hak kebebasan beragama tersebut tidak lantas membuat kehidupan antar agama menjadi damai dan rukun. Dengan artian masih banyak persoalan dan konflik yang terjadi yang dilatar-belakangi oleh perbedaan agama dan perbedaan cara penerimaan serta pemahaman terhadap agama. Salah satunya seperti yang terjadi di Kabupaten Sampang pada tanggal 29 Desember 2012 silam, dimana segerombolan massa melakukan penyerbuan dan pembakaran terhadap permukiman warga syiah yang ada di dusun Nangkrenang desa Karanggayam kecamatan Omben Kabupaten Sampang. Peristiwa ini kemudian menyeret pimpinan Syiah Sampang Tajul Muluk ke dalam penjara dengan tuduhan melakukan tindak pidana penodaan agama. Berdasarkan uraian di atas, isu Hukum dalam paper ini apakah putusan terhadap Tajul Muluk tentang penodaan agama mengesampingkan prinsip-prinsip hak kebebasan beragama bagi rakyat Indonesia.

\section{KONSEPSI HAK DAN KEBEBASAN BERAGAMA}

Sebelum menginjak lebih jauh terkait analisis putusan sebagaimana isu hukum di atas, penting kiranya disinggung mengenai konsepsi hak dan kebebasan beragama dalam kontek keindonesiaan. Menurut Al-Khanif (2010:108), kebebasan beragama mencakup hak untuk mempunyai atau menetapkan suatu agama atau kepercayaan dimana hak tersebut adalah hak untuk meyakini atau tidak meyakini sama-sekali suatu agama, baik yang bersifat theistik maupun yang bersifat nontheistik dan untuk memanifestasikan bentukbentuk ritual keagamaan secara sendiri-sendiri maupun di masyarakat dan di tempat umum atau pribadi seperti yang telah diatur dalam ketentuan HAM internasional. Terdapat beberapa instrumen hukum internasional yang mengatur tentang kebebasan beragama, antara lain; Deklarasi Universal Hak Asasi Manusia (DUHAM); The Declarations By General Assembly Resolutions 25 November 1981; Deklarasi Islam Universal tentang Hak Asasi manusia 1981; Konvensi Tentang Hak-Hak Anak Tahun 1989; Cairo Declaration on Human Right in Islam 1990; Deklarasi dan Aksi Wina 1993; Konvensi Internasional Tentang Perlindungan Hak Semua Buruh Migran dan Anggota Keluarganya 1990; dan International Convenant On Civil and Political Rights (ICCPR) 1966.

Sementara itu, Archot Krihnaswarni sebagaimana dikutip oleh Adam Muhshi membedakan dua unsur kebebasan beragama berupa unsur internal dan unsur eksternal dari agama dan keyakinan. Unsur internal agama dan keyakinan adalah kebebasan untuk melakukan 
semua hal berdasarkan ajaran agama dan keyakinan semisal keyakikan tentang Tuhan, nabi, rasul, malaikat, roh suci, kitab suci, hari kiamat, serta ajaran-ajaran agama yang bersifat trensendental lainnya. Unsur internal ini bersifat abstrak, tidak tampak karena ada di dalam hati dan pikiran setiap manusia yang mempercayainya dan pelaksanaannya tidak boleh dibatasi oleh entitas apapun termasuk undang-undang.

Sedangkan unsur eksternal agama dan keyakinan merupakan kebebasan untuk menjalankan praktik-praktik keagamaan atau keyakinan semisal shalat lima waktu, pergi ke gereja, menyembah patung, pohon, serta sesembahan lainnya dengan tujuan pelaksanaan ritual keagamaan sesuai tuntunan agama yang diyakini. Unsur eksternal ini merupakan manifestasi dari keyakinan yang ada di dalam hati dan pikiran manusia yang diwujudkan ke dalam beragam bentuk ritua keagamaan. Masing-masing ajaran agama tentunya memiliki elemen dasar tersebut karena untuk memanifestasikan ajaran agama yang abstrak (Muhshi, 2014:22).

Senafas dengan hal itu, Asma Jahangir sebagaimana dikutip oleh Adam Muhshi mengemukakan bahwa kebebasan beragama terdiri atas keyakinan dan manifestasi dari keyakinan tersebut. Keyakinan disebut dengan forum internum, sedangkan manifestasi keyakinan disebut dengan forum eksternum. Forum internum menyangkut kebebasan beragama yang bersifat abstrak karena ada dalam lubuk hati sanubari manusia. Hanya manusia yang meyakini agama-agama yang mampu mendefinisikan keyakinan sebagai bagian dari forum internum.

Sedangkan forum eksternum merupakan hak kebebasan beragama yang bersifat kasat mata karena berupa prilaku keagamaan dalam bentuk ritual tang termanifestasikan dari ajaran agama dan keyakinan yang dianut oleh manusia. Bentuk dari praktik keagamaan tersebut sangat beragam tergantung bagaimana ajaran agama tersebut diterima oleh manusia.

\section{PERTIMBANGAN HUKUM DIADILINYA TAJUL MULUK}

Pada bagian ini akan dibahas mengenai analisis putusan terhadap Tajul Muluk ditinjau dari prespektif kebebasan beragama dan berkeyakinan. Khusus pembahasan ini akan dilakukan kajian terhadap putusan pengadilan negeri sampang
Nomor 69/Pid.B/2012/PN.Spg. Tanggal 12 Juli 2012 yang dalam putusannya menyatakan bersalah kepada tajul Muluk karena telah melakukan tindak pidana penodaan agama yang memicu terjadinya disharmoni kehidupan masyarakat di desa karanggayam kabupaten Sampang serta menyulut terjadinya aksi kekerasan dan pembakaran terhadap permukiman warga syiah di desa sumber gayam kabupaten Sampang.

Putusan ini tentu menuai pro dan kontra di kalangan masyarakat. Kalangan yang pro menganggap bahwa dengan dipidananya Tajul Muluk maka akan membuat gerak langkah aliran sesat syiah akan lenyap dan keresahan di masyarakat akan lenyap. Sementara bagi kalangan yang kontra berpendapat bahwa dengan dipidananya Tajul Muluk, menyebabkan adanya pembiaran atau kelalaian dari negara untuk melindungi dan menjamin hak konstitusional warga negara dalam memilih dan menjalankan agama sesuai yang diyakininya. Dengan kondisi tersebut negara telah melakukan tindakan diskriminasi terhadap pemeluk agama minoritas yang ada di negeri ini.

Bertolak dari pemaran diatas, Seperti yang telah didakwakan oleh Jaksa penuntut Umum Kejaksaan Negeri Sampang Nomor 69/Pid.B/2012/ PN.Spg. Tanggal 12 Juli 2012. yang dibacakan pada hari rabu tanggal 4 Juli 2012 yang pada pokoknya menuntut kepada majelis hakim untuk menjatuhkan terdakwa Tajul Muluk alias H. Ali Murtadha telah terbukti secara sah dan meyakinkan bersalah melakukan tindak pidana penodaan agama Islam sebagaimana dalam dakwaan kesatu melanggar pasal 156a Kitab Undang-Undang Hukum Pidana (KUHP) serta menjatuhkan pidana terhadap terdakwa dengan pidana penjara selama 4 (empat) tahun penjara (Putusan Pengadilan Negeri Sampang Nomor 69/Pid.B/2012/PN.Spg).

Substansi dari ketentuan pasal 156a Kitab Undang-Undang Hukum Pidana ialah "Dipidana dengan pidana penjara selama-lamanya 5 tahun barang siapa dengan sengaja dimuka umum mengeluarkan perasaan atau melakukan perbuatan: (a) Yang ada pada pokoknya bersifat perusuhan, penyalahgunaan atau penodaan terhadap suatu yang dianut di Indonesia, (b) Dengan maksud agar orang tidak menganut agama apapun juga yang bersindikan Ketuhanan Yang maha Esa."

Sementara itu dalam putusan yang menjerat Tajul Muluk dengan pidana penjara 2 tahun penjara 
tersebut dengan tegas Majelis merumuskan adanya 2 fakta hukum bahwa saudara Tajul Muluk telah menyampaikan atau mengajarkan bahwa: (1) rukun iman ada 5, yaitu tauhidullah/ ma'rifatullah, annubuwwah (Kenabian), AlImamah (keimamahan), al 'adl (keadilan tuhan), al ma'aad (hari pembalasan); dan rukun Islam ada 8, yaitu : Shalat, puasa, zakat, khumus, haji, amar ma'ruf nahi mungkar, jihad, dan al-wilayah, (2) Al-Qur' an yang ada sekarang tidak asli (tidak orisinil).

Fakta pertama mengenai rukun Islam dan rukun iman majelis sependapat terhadap penjelasan yang dipaparkan oleh Zaenal Abidin Bagir, Umar Shahab, dan Zainun Kamal, yang pada pokoknya menyatakan bahwa bahwa rumusan 5 rukun iman dan 8 rukun islam secara substansi ada kesamaan dengan rumusan dengan rumusan 6 rukun iman dan 5 rukun islam yang secara umum dikenal oleh umat Islam Indonesia, lebih lanjut para ahli menjelaskan bahwa perbedaan jumlah tersebut lebih pada perbedaan pandangan dan tafsir atas Al-Qur' an, sehingga fakta ini tidaklah memenuhi unsur untuk menjerat saudara tajul muluk (putusan pengadilan Sampang).

Merujuk pada pandangan Islam tentang golongan, nabi Muhammad pernah bersabda bahwa kelak dikemudian hari, umat Islam akan mengalami perpecahan mencapai 73 golongan. Akar perpecahan ini dimulai pada masa Khalifah Ali bin Abi Thalib dimana saat itu umat Islam terpecah menjadi tiga golongan, namun dalam masa tersebut perpecahan hanya sebatas pada masalah politik kepemimpinan.

Menurut Zainal Abidin Bagir, masalah kelompok aliran dalam Islam sudah berlangsung sejak ratusan tahun yang lalu. Bahkan dari saking beragamnya aliran dan kelompok dalam Islam, pada tahun 2005 para ulama' dari berbagai madzhab mengadakan konferensi yang berlangsung di Jordania, Keputusan dari konferensi tersebut ialah: (1) siapa saja yang mengikuti dan menganut salah satu dari empat madzhab Ahlus Sunnah (Syafi'i, Hanafi, Maliki, Hanbali), dua madzhab Syiah (Ja'fari dan Zaydi), madzhab Ibadi dan madzhab Zhahiri adalah Muslim, (b) madzhabmadzhab tersebut sepakat pada lima rukun Islam: dua kalimat syahadat, kewajiban shalat, zakat, puasa di bulan Ramadhan dan Haji ke Baitullah di Makkah serta percaya pada dasar-dasar akidah Islam: percaya pada Allah, para Malaikat-Nya, kitab-kitab-Nya, para Rasul-Nya, hari akhir, dan takdir, mereka yang percaya termasuk orang Islam (Muslim);

Seharusnya hal kekerasan dan penghakiman tidak perlu terjadi dalam kehidupan beragama di Indonesia, umat muslim sudah selayaknya menghargai perbedaan yang ada ditengah-tengah kehidupannya. Perbedaan selayaknya dijadikan alat untuk mempersatu dan memperkuat bangsa, karena dengan perbedaan itulah sebuah bangsa akan menjadi kuat, tangguh dan penuh dengan keindahan. Dalam hal ini harus diperkuat pemahaman bahwa tugas umat muslim (terlepas siapapun orang dan latar-belakangnya) terhadap umat muslim lain bahkan kepada umat dari agama lain hanya pada tataran mengajak, membimbing dan mengarahkan, bukan untuk memfonis apalagi memusnahkannya dari muka bumi karena perkara tersebut merupakan urusan Tuhan.

Berlanjut pada fakta kedua tentang perbuatan tajul muluk menyampaikan atau mengajarkan bahwa Al-Qur'an yang ada sekarang tidak asli (tidak orisinil), majelis hakim memandang bahwa perbuatan tersebut telah jelas merendahkan mengotori dan merusak keagungan Al-Qur'an , mengingat sebagaimana menjadi pengetahuan umum bahwa Al-Qur'an merupakan kitab suci bagi umat islam yang terjaga kemurniannya karena sudah dijamin pemeliharaannya (kemurniannya) oleh Allah SWT, sebagaimana disebutkan dalam Al-Quran surat al Hijr ayat 9.

Dalam fakta hukum yang kedua ini, dasar pemakaian dalil Al-Qur'an Surat Al-Hijr ayat Sembilan yang kemudian dijadikan dasar pijakan bahwa perbuatan tajul muluk telah jelas melakukan perusuhan, penyalahgunaan dan penodaan terhadap agama islam. Menurut majelis tajul muluk telah memenuhi unsur dari pasal 156a Kitab Undang-Undang Hukum Pidana. Dalam hal ini pemakaian dalil sebagai pijakan dijeratnya tajul muluk perlu dikaji ulang, mengingat dalam penggunaan dalil Al-Qur'an untuk memutuskan sesuatu perkara keagamaan haruslah disertai dengan penafsiran yang telah diakui kebenarannya. Sedangkan kalau menyimak pada penggunaan dalil yang dilakukan Majelis Hakim saat menjerat Tajul Muluk tidaklah diiringi dengan tafsiran Al-Quran yang dipakai. Sehingga hal ini seolah pemidanaan terhadap Tajul Muluk terkesan dipaksakan.

Amanat Pasal 1 ayat (2) Deklarasi Tentang Penghapusan Segala Bentuk Intoleransi dan Diskriminasi Berdasarkan Agama dan Kepercayaan 
25 November 1981 menyatakan bahwa "tidak seorangpun dapat dijadikan sasaran pemaksaan yang akan mengurangi kebebasannya untuk menganut suatu agama atau kepercayaan pilihannya". Jika berpijak pada bunyi pasal tersebut maka tidak seharusnya timbul adanya penghakiman terhadap Tajul Muluk, jika fakta hukum yang dijadikan pijakan adalah pernyataan tajul muluk yang mengatakan bahwa Al-Qur'an yang ada sekarang tidak asli (tidak orisinil) mengingat dasar penggunaan tafsirannya pun juga tidak jelas perujukannya.

Pada tahun 2007 Majelis Ulama Indonesia mengeluarkan Fatwa tentang 10 (sepuluh) kriteria aliran sesat, antara lain ialah: (a) mengingkari salah satu rukun iman dan rukun Islam, (b) meyakini atau mengikuti akidah yang tidak sesuai dengan dalil syar'i (Al Qur'an dan Sunnah), (c) meyakini turunnya wahyu setelah Al Qur'an, (d) mengingkari autentisitas dan kebenaran $\mathrm{Al}$ Qur'an, (e) menafsirkan Al Qur'an yang tidak berdasar kaidah-kaidah tafsir, (f) mengingkari kedudukan Hadits sebagai sumber ajaran Islam, (g) melecehkan/mendustakan Nabi dan Rasul, (h) mengingkari Nabi Muhammad sebagai Nabi dan Rasul terakhir, (i) mengurangi/menambah pokokpokok ibadah yang tidak ditetapkan syari' ah, dan (j) mengkafirkan sesama muslim hanya karena bukan kelompoknya.

Kalau merujuk pada fatwa MUI tersebut berdasarkan fakta hukum yang ditegaskan oleh majelis hakim, memang secara implisit Tajul Muluk bersalah karena menyatakan bahwa Al-Qur'an yang ada saat ini sudah tidak asli, hal ini telah sesuai dengan poin keempat dari rumusan Fatwa tersebut. Akan tetapi menjadi bias ketika melihat kedudukan Fatwa MUI sebagai sumber rujukan norma hukum, lagipula majelis tidak menjelaskan bahwa ketentuan Al-Qur'an yang tidak asli tersebut merujuk pada ketentuan Fatwa Kriteria sesat MUI.

Menurut Zainal Abidin Bagir, perdebatan masalah keaslian mushaf Al-Qur'an tidak hanya terjadi pada kaum syiah, tetapi telah terjadi pula pada umat Islam yang berpahan sunni, ini merupakan perdebatan klasik. Jadi selama kelompok tersebut mengumani Al-Qur'an, maka orang tersebut tidak bisa dianggap sebagai aliran sesat apalagi dituduh sebagai penistaan agama. Dengan demikian, diadilinya tajul muluk hanya karena perbedaan pendapat tentang sekte keagamaan jelas telah melanggar pirnsip-prinsip Hak Asasi manusia yang mana Indonesia telah mengakui dengan tegas hak-hak tersebut dalam konstitusinya. Kostitusi melalui amandemen ke empat UUD 1945 mengatur tentang kebebasan beragama. Pasal 29 ayat (2) telah menegaskan bahwa "Negara menjamin kemerdekaan tiap-tiap penduduk untuk memeluk agamanya masingmasing dan untuk beribadat menurut agamanya dan kepercayaannya itu".

Dengan redaksi yang hampir sama, pasal 22 ayat (1) Undang-undang hak asasi manusia menyatakan bahwa "setiap orang bebas untuk memeluk agamanya masing-masing dan untuk beribadat meneurut agamanya dan kepercayaannya itu". Dengan demikian terkait dengan ajaran yang disyi' arkan oleh Tajul Muluk, seharusnya tidak ada pertentangan apalagi gangguan terhadap Tajul Muluk beserta para pengikutnya, karena hal itu sudah jelas dijamin oleh negara.

Perlu diperhatikan, dalam tragedi konflik syiah-sunni sampang, Tajul Muluk merupakan korban dengan kerugian rumah dan komplek pesantrennya musnah dibakar massa. Bagaimana bisa, seorang korban dengan segala kerugian dan penderitaannya, menjadi aktor utama tindak kekerasan dan pembakaran. Seharusnya, yang layak diproses di meja hijau adalah aktor/otak penyerangan dan pembekarannya, bukan korbannya. Oleh karena itu, tindakan untuk menyeret tajul muluk ke penjara melalui meja pengadilan sama sekali bertentangan dengan prinsip hak asasi manusia. Ada tudingan bahwa proses peradilan yang dilakukan terhadap tajul muluk telah menyalahi hukum formil. Menurut Pasal 156a KUHP perbuatan yang dapat dikriminalisasikan ada 2 , yaitu: penyimpangan pokok-pokok agama dan mengajak orang untuk atheis. Faktanya tidak ada kegiatan atau ucapan Tajul Muluk yang berlawanan dan menyimpang dari ajaran pokok Islam dan juga tidak pernah mengajak untuk tidak bertuhan (atheis).

Dalam kontek ini, Majelis Hakim telah tidak mengindahkan amanat Pasal 3 Ayat (2) Undangundang Hak Asasi Manusia yang menyatakan "setiap orang berhak atas pengakuan, jaminan, perlindungan, dan perlakuan hukum yang adil serta mendapat kepastian hukum dan perlakuan yang sama di depan hukum", selanjutnya, Majelis hakim juga telah mengabikan ketentuan pasal 3 Ayat (3) yang menyatakan "Setiap orang berhak atas perlindungan hak asasi manusia dan kebebasan dasar manusia, tanpa diskriminasi”. 
Pendapat demikian bukanlah tanpa alasan, karena hak untuk beragama dan menjalankan peribadatan keagamaannya merupakan hak dasar manusia yang telah dijamin oleh konstitusi, Pasal 28 E Ayat (1) serta Pasal 28 E ayat (2) UUD 1945, Pasal 22 ayat (1) Undang-undang Nomor 39 Tahun 1999 Tentang Hak Asasi Manusia. Oleh karenanya, keberadaan hak dasar tersebut wajib dihormati, dilindungi dan dijunjung tinggi, dan tidak pernah dibenarkan adanya tindakan yang mengganggu, mengabaikan, mengurangi, apalagi merampas hak dasar tersebut (Pasal 1 UU No.39 Tahun 1999).

Jelaslah bahwa dalam hal ini Majelis hakim telah melanggar ketentuan undang-undang nomor 39 tahun 1999 tentang hak asasi manusia. Pasal 17 menyatakan bahwa "Setiap orang, tanpa diskriminasi, berhak untuk memperoleh keadilan dengan mengajukan permohonan, pengaduan, dan gugatan, dalam perkara pidana, perdata, maupun administrasi serta diadili melalui proses peradilan yang bebas dan tidak memihak, sesuai dengan hukum acara yang menjamin pemeriksaan yang obyektif oleh hakim yang jujur dan adil untuk memperoleh putusan yang adil dan benar.

Selain hukum nasional, penjatuhan putusan terhadap Tajul Muluk tersebut telah nyata menyimpang dari ketentuan pasal 18 DUHAM yang menegaskan bahwa kebebasan menganut suatu agama merupakan hak dasar yang tidak bisa diganggu-gugat oleh pihak manapun. Selain itu, terdapat juga kebebasan yang dimiliki setiap manusia untuk melakukan aktifitas keagamaannya serta menyampaikan ajaran keagamaannya, tanpa adanya gangguan yang menyebabkan terampasnya hak dasar tersebut. Oleh karenanya tindakan mengganggu, merampas, mengusir, melakukan kekerasan, membatasi, dan perbuatan-perbuatan lain yang sebangsa, merupakan perbuatanperbuatan yang tidak dibenarkan oleh deklarasi ini.

\section{KEDUDUKAN FATWA MUI}

Majelis Ulama Indonesia (MUI) berdiri pada 26 Juli 1975 di Jakarta pada acara Musyawarah Nasional Ke-1 MUI yang berlangsung dari 21-27 Juli 1975. Terkait dengan pendirian MUI, ada dua alasan yang dikemukakan Presiden Soeharto: (1) keinginan pemerintah untuk melihat umat Islam bersatu; (2) menyadari bahwa banyak problem yang dihadapi bangsa tidak dapat diatasi tanpa bantuan ulama.
Di bawah kekuasaan Orde Baru (Orba), MUI menjelma menjadi lembaga semi-negara yang banyak memberikan legitimasi kepada pemerintah saat itu. Hal ini dilakukan dengan cara: (1) abstain atau tidak mengeluarkan fatwa dalam kasus yang dilematis (seperti kasus SDSB); (2) MUI tidak dibolehkan aktif dalam politik praktis dan hanya berfungsi untuk mengomunikasikan program pembangunan kepada masyarakat dan menjadi mediator komunikasi antara pemerintah, rakyat, dan ulama. Oleh karena itu, pemerintah kemudian memosisikan MUI sebagai representasi umat Islam yang sah yang keputusan-keputusannya selalu mendapat dukungan pemerintah (Hamdi, 2007:85124).

Sebagaimana yang dicantumkan dalam putusan Pengadilan Negeri Sampang yang mencatat surat rekomendasi dan fatwa pimpinan cabang majelis ulama Indonesia (MUI) Kabupaten Sampang Nomor A-37/MUI/Spg/1/2012 tanggal 17 Januari 2012 perihal ajaran atau aliran syiah Imamiyah. Fatwa adalah sebuah istilah mengenai pendapat atau tafsiran pada suatu masalah yang berkaitan dengan hukum Islam. Fatwa sendiri dalam bahasa Arab artinya adalah "nasihat", "petuah", "jawaban" atau "pendapat". Keputusan atau nasihat resmi yang diambil oleh sebuah lembaga atau perorangan yang diakui otoritasnya, disampaikan oleh seorang mufti atau ulama, sebagai tanggapan atau jawaban terhadap pertanyaan yang diajukan oleh peminta fatwa (mustafti) yang tidak mempunyai keterikatan. Dengan demikian peminta fatwa tidak harus mengikuti isi atau hukum fatwa yang diberikan kepadanya. Dalam kontek keindonesiaan, fatwa dikeluarkan oleh Majelis Ulama Indonesia sebagai suatu keputusan tentang persoalan ijtihadiyah yang terjadi di Indonesia guna dijadikan pegangan pelaksanaan ibadah umat Islam di Indonesia.

Berdasarkan pencantuman Surat rekomendasi dan fatwa MUI Kabupaten Sampang itu muncul suatu pertanyaan publik tentang kedudukan fatwa MUI kabupaten Sampang tersebut sebagai salah satu barang bukti serta menjadi rujukan norma hukum di Indonesia, jika melihat ketentuan pasal 2 ayat (1) Penetapan Presiden Republik Indonesia Nomor 1/PNPS Tahun 1965 Tentang Pencegahan penyalahgunaan dan/atau penodaan agama yang berbunyi "Barang siapa melanggar ketentuan tersebut dalam pasal 1 diberi perintah dan peringatan keras untuk menghentikan perbuatannya itu di dalam suatu 
keputusan bersama Menteri Agama, Menteri/ Jaksa Agung dan Menteri Dalam Negeri. Pasal 1 PNPS tahun 1965 menjelaskan bahwa "Setiap orang dilarang dengan sengaja di muka umum menceritakan, menganjurkan atau mengusahakan dukungan umum, untuk melakukan penafsiran tentang sesuatu agama yang dianut di Indonesia atau melakukan kegiatan-kegiatan keagamaan yang menyerupai kegiatan-kegiatan keagamaan dari agama itu, penafsiran dan kegiatan mana menyimpang dari pokok-pokok ajaran agama itu".

Jika merujuk pada ketentuan pasal 2 ayat (1) Penetapan Presiden Nomor 1/PNPS Tahun 1956 tersebut maka seharusnya yang memberikan rekomendasi terhadap kasus Tajul Muluk ialah keputusan bersama Menteri agama, Menteri/ Jaksa Agung dan Menteri Dalam Negeri. Namun pada kenyataannya, dalam kasus ini, yang memberikan rekomendasi ialah Majelis Ulama' Indonesia Kabupaten Sampang.

Amanat Pasal 2 Ayat (1) Deklarasi Tentang Penghapusan Semua Bentuk Intoleransi antar Umat beragama menyatakan bahwa "tidak seorang pun boleh dijadikan sasaran diskriminasi oleh Negara, lembaga, kelompok orang-orang, atau orang manapun atas alasan-alasan agama atau kepercayaan lain". Semestinya kalau memang Tajul Muluk dianggap bersalah telah melakukan penodaan terhadap agama, maka hal yang harus ditempuh terlebih dahulu ialah perlunya keputusan bersama antara Menteri Dalam Negeri, Menteri Agama dan Jaksa Agung. Hal ini telah jelas diatur dalam ketentuan pasal 2 ayat (1) Penetapan Presiden Nomor 1/PNPS Tahun 1956, "Barang siapa melanggar ketentuan tersebut dalam pasal 1 diberikan perintah dan peringatan keras untuk menghentikan perbuatannya itu dalam suatu keputusan bersama Menteri Agama, Menteri/ Jaksa agung dan Menteri Dalam Negeri." Tindakan pengabaian terhadap amanat Penetapan Presiden Nomor 1/PNPS Tahun 1956 merupakan tindakan yang melalaikan prosedur hukum yang berakibat pada adanya diskrimanasi terhadap hak anak bangsa.

Selain pencantuman rekomendasi MUI Kabupaten Sampang sebagai alat bukti, Majelis juga memasukkan surat pernyataan sikap Pengurus Cabang Nahdlatul Ulama Kabupaten Sampang Nomor: 255/EC/A.2/L-361/1/2012 tertanggal 2 Januari 2012. Hal ini juga menimbulkan pertanyaan bagaimana status hukum keberadaan Pernyataan sikap PC NU tersebut.
Disamping itu hal tersebut juga menimbulkan kesan adanya pengaruh kaum mayoritas dalam proses hukum yang dialami oleh Tajul Muluk.

\section{HEGEMONI MAYORITAS}

Seperti yang telah disebutkan diatas, bahwa dalam penyelesaian proses hukum yang menimpa Tajul Muluk terkesan kuatnya pengaruh hegemoni mayoritas utamanya dalam proses pelaksanaan hukum acara. Hal tersebut semakin meyakinkan publik ketika dicantumkannya surat pernyataan sikap pengurus cabang Nahdlatul Ulama Kabupaten Sampang nomor 255/EC/A.2/L-361/ 1/2012 tertanggal 2 Januari 2012.

Putusan tersebut hanyalah memuat pernyataan sikap dari Pengurus Cabang Nahdlatul Ulama, sedangakan organisasi keagamaan yang ada dikabupaten sampang bukan hanya Nahdlatul Ulama semata. dalam hal ini putusan tersebut sama-sekali tidak mencantumkan pernyataan sikap dari organisasi keagamaan yang lain, misalkan pernyataan sikap dari Pengurus Daerah Muhammadiyah Sampang, pengurus cabang Hisbut Tahrir Indonesia (HTI) Kabupaten Sampang, Pengurus Font Pembela Islam (FPI) kabupaten Sampang dan pengurus Cabang AlIrsyad Kabupaten Sampang.

Adanya pengaruh hegemoni mayoritas dalam pelaksanaan proses hukum yang dialami oleh Tajul Muluk semakin mengemuka mengingat Nahdlatul Ulama merupakan satu-satunya organisasi keagamaan yang mempunyai anggota atau massa yang paling banyak dibandingkan organisasi keagamaan lain yang ada di daerah ini.

Undang-undang dasar Republik Indonesia Tahun 1945 secara eksplisit dan tegas tegas menyatakan di dalam Pasal 1 ayat (3) UUD 1945 yang berbunyi bahwa Negara Indonesia adalah Negara Hukum. Disamping itu konstitusi juga menempatkan rakyat pada posisi yang sangat strategis dalam system ketatanegaraan, hal tersebut dibuktikan dengan bunyi Pasal 1 ayat (2) Undang-undang dasar Negara Republik Indonesia tahun 1945 " Kedaulatan berada di tangan rakyat dan dilaksanakan menurut undang-undang dasar". Dari bunyi kedua pasal tersebut menandakan bahwa Indonesia merupakan Negara hukum yang berlandaskan demokrasi.

Pada intinya, syarat dan prinsip Negara hukum haruslah memuat tentang harus ada pengakuan, perlindungan dan penegakan terhadap 
hak-hak asasi manusia serta adanya kebebasan dan kemandirian kekuasaan kehakiman terutama dalam fungsinya untuk menegakkan hukum agar dalam membuat dan menerapkan hukum atau peraturan perundang-undangan tidak bertindak sewenang-wenang, yang pada akhirnya menciptakan suatu kehidupan bermasyarakat, berbangsa dan bernegara menuju terciptanya kehidupan yang tertib dan damai.

Selaras dengan pernyataan tersebut, Undang-undang Dasar Republik Indonesia tahun 1945 melalui pasal 24 Ayat (1) dengan tegas menyatakan bahwa "kekuasaan kehakiman merupakan kekuasaan yang merdeka untuk menyelenggarakan peradilan guna menegakkan hukum dan keadilan". Pasal tersebut mengindikasikan bahwa konstitusi telah mengamanatkan akan pentingnya kekuasaan kehakiman yang bebas dari campur tangan siapapun, karena hanya dengan cara tersebut citacita penegakan hukum dan keadilan dapat terlaksana dengan baik dan benar (Hamzah, 2008:100).

Apabila terjadi suatu proses peradilan yang dalam persidangannya dipenuhi oleh campur tangan berbagai pihak diluar pengadilan, maka bisa dipastikan kwalitas putusan tersebut tidak memberikan dan menghadirkan keadilan bagi rakyatnya. Keadaan seperti tersebut diatas hanya akan menambah penderitaan yang tidak ada ujung pangkalnya serta berpotensi tercabutnya hak-hak dasar yang melekat pada masing-masing manusia.

Terkait adanya masalah timbulnya pengaruh kelompok mayoritas dalam proses hukum yang menjerat tajul Muluk berdasarkan deklarasi penghapusan semua bentuk intoleransi dan diskriminasi berdasarkan agama dan kepercayaan. Deklarasi menegaskan dalam pasal 1 ayat (3) bahwa : "kebebasan untuk mewujudkan agama atau kepercayaan seseorang hanya boleh tunduk pada pembatasan-pembatasan seperti yang ditetapkan oleh undang-undang dan yang diperlukan untuk melindungi keselamatan umum, ketertiban umum, kesehatan masyarakat, atau kesusilaan umum ketertiban umum, kesehatan masyarakat atau kesusilaan umum atau hak-hak dan kebebasan-kebebasan fundamental orang lain."

Konkretnya, selama prinsip-prinsi dalam konsepsi Negara hukum dan demokrasi belum dipenuhi oleh negara, maka selama itu pula akan terjadi berbagai pelanggaran dan kejahatan terhadap prinsip hak asasi manusia, menjadi Negara anarkis, serta tercipta para penguasa yang bertindak sewenang-wenang dalam menjalankan kewenangannnya.

Negara Indonesia melalui beberapa peraturan perundang-undangannya telah menegaskan bahwa sebagai Negara hukum, maka setiap warga negara, berhak atas perlindungan, perlakuan, jaminan, dan mendapatkan kepastian yang adil dan perlakuan yang sama di depan hukum. oleh karena setiap pengabaian terhadap ketentuan ini merupakan sebuah pengabaian atas ketentuan yang berlaku di Indonesia.

Negara juga menjamin adanya bantuan serta perlindungan yang adil dari pengadilan yang objektif dan tidak berpihak. Dengan demikian, tindakan yang membela golongan mayoritas dan mengucilkan kaum minorotas merupakan tindakan diskriminasi yang menyebabkan melebarnya kesenjangan masyarakat dalam mendapatkan akses keadilan yang merata.

Berdasarkan uraian tersebut diatas, baik dalam konsepsi hukum ataupun dalam ketentuan The Declarations By General Assembly Resolutions 25 November 1981, serta aturan lain mulai dari Undang-undang Dasar 1945, UndangUndang Hak Asasi Manusia, serta aturan lain tentang hak asasi manusia, pada dasarnya tidaklah dibenarkan adanya pengaruh kelompok mayoritas dalam melaksanakan suatu proses hukum seseorang. Dalam proses hukum yang dialami oleh Tajul Muluk, adanya pengaruh hegemoni mayoritas tercermin dalam pencantuman pernyataan sikap Pengurus Cabang Nahdlatul Ulama Kabupaten Sampang sebagai salah-satu bukti, tanpa mencantumkan pernyataan sikap dari organisasi-organisasi keagamaan lainnya yang berada di Kabupaten Sampang.

Berbagai analisa yang telah dipaparkan diatas, bisa ditarik benangnya bahwa Negara telah mengabaikan prinsip-prinsip hak asasi manusia berupa kebebasan beragama dan kebebasan beribadah atau menjalankan ritual agama bagi rakyat Indonesia. Karena pada dasarnya akal pikiran dan keyakinan tidak selayaknya diadili.

\section{SIMPULAN}

Berdasarkan penjelasan di atas, simpulan ialah bahwa putusan terhadap Tajul Muluk di atas menngesamipingkan prinsip kebebasan beragama yang dijamin oleh Konstitusi dan peraturan perundang-undangan di bawahnya. 
Pengesampingan tersebut didasarkan pada pertimbangan penjatuhan putusan terhadap tajul Muluk, majelis hakim telah melakukan diskriminasi dan bertentangan dengan prinsip hak asasi manusia yang khusus mengenai kebebasan beragama telah diatur dalam pasal 18 DUHAM, Pasal 1 Ayat (2) Deklarasi PBB 25 November 1981, Pasal 28E Ayat (1), ayat (2) dan Pasal 29 Ayat (2) UUD 1945, Pasal 22 Ayat (1) dan Ayat (2) UU HAM.

Selain Itu, terdapat 3 (tiga) hal dalam proses peradilan yang berpotensi menimbulkan sikap diskriminasi, antara lain ; Pertama, kedudukan Fatwa MUI Kabupaten Sampang yang dijadikan

\section{DAFTAR RUJUKAN}

Al-Khanif. 2010. Hukum dan Kebebasan Beragama di Indonesia. Yogyakarta; LakBang Mediatama.

Fadjar, A. M. 2004. Tipe Negara Hukum. Bayu Media dan Intrans Publishing, Malang,

Hamdi, A.Z. 2007. Radikalisme Islam Melalui Institusi Semi-Negara: Studi Kasus Atas Peran MUI Pasca Soeharto, Jurnal Istiqro', Volume 06, Nomor 01.

Hamzah, A. 2008. Hukum Acara Pidana Indonesia. Jakarta; Sinar Grafika

Muhshi, Adam. 2014. Teologi Konstitusi; Hukum Hak Asasi Manusia Atas Kebebasan Beragama di Indonesia. Yogyakarta: LKiS.

Deklarasi Universal Hak-Hak Asasi Manusia (Resolusi Majelis Umum PBB Nomor Tahun 1948) sebagai salah satu dari keseluruhan alat bukti, sedangkan menurut ketentuan pasal 2 ayat (1) Penetapan Presiden Nomor 1/PNPS Tahun 1956 ialah diperlukan adanya keputusan bersama antara Menteri Dalam Negeri, Menteri Agama dan Jaksa Agung. Kedua, adanya pengaruh hegemoni mayoritas dalam proses hukum yang dialami oleh Tajul Muluk, hal ini nampak dari adanya pernyataan sikap dari pengurus cabang Nahdlatul Ulama Kabupaten Sampang dalam Alat Bukti, sementara pernyataan sikap dari organisasi keagamaan yang lain tidak dimasukkan

The Declarations on the Eliminations of All Froms of Intolerance and of Discriminations Based on Religions or Belief Proclaimed by General Assembly Resolutions 36/55 of 25 November 1981.

Undang-Undang Nomor 39 Tahun 1999 Tentang Hak Asasi Manusia. (Lembaran Negara Republik Indonesia Tahun 1999 Nomor 165)

Penetapan Presiden Nomor 1/PNPS Tahun 1956 Tentang Pencegahan Penyalahgunaan dan/ atau Penodaan Agama. (Lembaran negara republik indonesia tahun 1965 nomor 3.)

Putusan Pengadilan Negeri Sampang Nomor 69/ Pid.B/2012/PN.Spg. Tanggal 12 Juli 2012. 